\title{
Clean Manufacturing and Green Practices in the Apparel Supply Chain
}

\author{
Sonia Akter ${ }^{1}$, Xiaofen Ji1*, Md. Maruf Sarker¹, Liling Cai', Yibing Shao', Md. Kamrul Hasan', \\ Sabbir Ahmed Abir ${ }^{2}$, Vincent Quan ${ }^{3}$
}

\author{
${ }^{1}$ School of International Education, Zhejiang Sci-Tech University, Hangzhou, China \\ ${ }^{2}$ BGMEA University of Fashion and Technology, Nishatnagar, Turag, Bangladesh \\ ${ }^{3}$ Fashion Institute of Technology, State University of New York, USA \\ Email: *xiaofenji@zstu.edu.cn
}

How to cite this paper: Akter, S., Ji, X.F., Sarker, Md.M., Cai, L.L., Shao, Y.B., Hasan, Md.K., Abir, S.A. and Quan, V. (2020) Clean Manufacturing and Green Practices in the Apparel Supply Chain. Open Journal of Business and Management, 8, 104-113. https://doi.org/10.4236/ojbm.2020.81007

Received: November 9, 2019

Accepted: December 13, 2019

Published: December 16, 2019

Copyright $\odot 2020$ by author(s) and Scientific Research Publishing Inc. This work is licensed under the Creative Commons Attribution International License (CC BY 4.0).

http://creativecommons.org/licenses/by/4.0/

\begin{abstract}
Considering environmental sustainability in the apparel supply chain, the aim of this manuscript is to describe the current trends, such as efficient energy consumption, reuse and recycling, green design and life cycle design, life cycle assessment, reverse logistics, green supplier, green branding, and green marketing considering clean manufacturing and green supply chain management (GSCM) practices for the green apparel supply chain. The primary focus is on the description of clean manufacturing and GSCM practices. Finally, challenges and future research directions are revealed. So, the contribution of this paper may provide equal benefits for both researchers and practitioners.
\end{abstract}

\section{Keywords}

Cleaner Production, Green Practices, Apparel Supply Chain, Green Supply Chain Management

\section{Introduction}

The textile and apparel industries are the second largest polluting industry in the world [1]. This unexpected ranking is mainly due to growth of "Fast fashion", which implies that the current textile and apparel industries are not sustainable [2]. For example, cheap, trendy clothing which has a shorter life cycle accelerates the need for using more textile materials and chemicals. As a result, water and air pollution are increasing, causing severe environmental pollution. However, for the business sustainability, a huge number of apparel brands such as Patagonia, $H$ \& M's, Levi's, and Loomstate are accepting environmental sustainability 
(green practices) as their core brand strategy [3]. Apparel industries are focusing more on environmental performance to improve their efficiency, profitability and corporate image in the global market [4]. Moreover, a study by Chris K.Y. Lo et al., reveals that the adoption of ISO 14,000 in the EMS, improves manufacturers' profitability [5]. The concept of integrating environmental thinking into supply chain management is called GSCM [6] [7]. Clean manufacturing and technology have become a common trend in environmental protection in the textile and apparel industries. The main targets of clean manufacturing and GSCM practice are to reduce emissions of environmental deteriorating gas, chemical and solid waste throughout the supply chain during raw material collection, product design, manufacturing processes, and delivery of final products in order to improve environmental performance. In addition, efficient energy use has become a major concern for cleaner production in the textile and apparel industries. According to Saberi et al., investing in energy efficient technology not only reduces environmental negative impacts of production and delivery of products, but also minimizes production and transportation costs [8]. Consequently, this paper focuses on environmental sustainability based on clean manufacturing and GSCM practices in the apparel supply chain.

\section{Grounds for Green Practices in the Apparel Supply Chain}

In the 1960s people had started thinking about the industrialized society. From that time, they were worried about consumptions of industrialized products as the technologies had been helping to use more natural resources in unsustainable ways. To cope with these situations, eco-movement ideas were revealed. Actually, the eco-movement idea got maximum popularity at the end of the 1970s because of consumer interest in eco-friendly products. That movement has influenced the thoughts of today's society [9] [10]. However, eco-friendly or green apparel is made from sustainable resources. This eco-friendly, environmentally friendly and sustainable terms consider product life cycle assessment from its raw materials collection to the final disposal after use and its impact on the planet [11] [12]. Environmentally-friendly production means to integrate the continuous utilization of environmentally friendly approaches and services to processes cleaner products targeting to improve efficiency and to reduce the risks to the planet. In other words, production of ecologically friendly apparels needs to consider eco-friendly approaches and clean manufacturing technology such as green design, organic raw materials sourcing, eco-friendly product manufacturing, sustainable distribution (transportation) to the channels and also considering their reverse logistics, and environmentally friendly waste management [12].

\section{Clean Manufacturing and Green Practices in the Apparel Supply Chain}

\subsection{Efficient Energy Consumption}

Efficient energy consumption is the basic need for cleaner production. Energy 
consumption in the apparel industry is high and increasing steadily. As a result, the topic of energy saving has become perhaps one of the most important issue in this area. In the realm of the green movement, efficient energy consumption and use of renewable energy have received significant attention [13]. In order to reduce carbon emission and to increase energy efficiency, many apparel industries are using solar water heating and heat energy recycling [14]. Research has acknowledged that cooling system upgrades, energy-efficient sewing machines, load shifting, and lighting systems etc. are the common points of energy savings in the apparel industry [13]. Noteworthy attention has given to the identification of the Energy Efficient Technology (EET) for the apparel manufacturing industries, where they have focused mainly on the introduction of new EET to the apparel industry [15] [16]. In addition to that, authors Pathirana S., Yarime M., have analyzed several factors influencing the diffusion of energy-efficiency technologies for the apparel industry in the small- and medium-sized enterprises (SMEs) of Sri Lanka [13].

Karen et al. have identified different energy saving factors (use of materials, designing of the products, and control of operational activities) considering different stages of product lifecycle (manufacturing stage, utilization stage, and disposal stage) for sustainable fashion products [17]. However, consumer pressure, cost savings, and carbon emission reductions are the main drivers for accepting energy saving initiatives and clean technology in the apparel industry [13].

\subsection{Reuse and Recycling}

According to Fortuna and Diyamandoglu the term "textile reuse" means enhancing the service life of the textile product by shifting it to the new owners which can be accomplished by borrowing, trading, swapping, and inheriting through flea markets, second hand shops, online marketplaces, clothing libraries, and garage sales [18]. On the other hand, textile recycling represents the reprocessing of pre-or post consumer products into new products or non-textile products. More and more reuse and recycling of textile/apparel products would minimize the consumption of virgin materials and could also help achieve environmentally friendly manufacturing. Although, reuse and recycling are more beneficial than land filling, there are certain scenarios where reuse and recycling are not beneficial for the environment, for example, when replacement rates in the market are low, and recycling processes require harmful chemicals [19].

\subsection{Green Design and Life Cycle Design}

Design decisions have great influences on the entire business model especially from a sustainability point of view. To meet consumers green demands by supplying fashion products emulate a new business direction to the fashion entrepreneurs [17]. Implementation criteria of green design refer to low materials and energy consumption, biodegradable product design, reusable, recyclable, recoverable materials and component parts design, zero waste mechanisms, natural 
dyeing techniques, slow fashion methods, and cooperation with customers for eco-design [20]. Similarly, life cycle design (LCD) might be the one way to conceive environmentally conscious new products to reduce waste from the apparel and textile supply chain. The vision of life cycle design (LCD) methodology is to minimize all the possible negative effects from the pre-production to after consumption stages.

\subsection{Life Cycle Assessment}

Life cycle assessment (LCA) is used to assess environmental performance of a product in each and every stage of its entire life span from raw material cultivation to after use disposal. LCA for environmental impact often depends on life cycle inventory data [21] and honest collaborative information sharing among the supply chain partners. The method of life cycle assessment has been used by Sohail et al. to examine the environmental impacts for flame retardant cotton textiles before and after eco-path disposal treatment [22]. LCA tool has been used in several research papers in order to get information about energy consumption, and green house gas emissions. For example, Xing et al., has presented a cloud-based life-cycle assessment (LCA) platform to collect and interchange real time data. They have used a cotton T-shirt to assess the carbon footprint using a life-cycle assessment (LCA) platform [21].

\subsection{Reverse Logistics}

Waste management and cleaner production are gaining huge popularity in the textile and apparel sectors due to reduction of landfill spaces, and diminishment of natural resources. In addition, low prices and frequent changes in the style of apparel products encourage greater levels of apparel consumption which in turn produces huge disposal of fashion apparel. As a result, practices of sustainable logistics are becoming more challenging [23] [24]. Reverse logistics is strongly related with the term circular economy which, in turn, is closely related to reuse, recycling, and reducing of raw materials during the production process [25] [26]. In other words, remanufacture, repair, refurbishment, recycling, sharing, and take-back are the activities in a circular business model compared with the traditional (linear business) model [27]. In addition, sustainable/green logistics, and reverse supply chain management are the most commonly explored research topics in the field of logistics having tremendous amounts of qualitative and quantitative research [28].

\subsection{Green Supplier}

Supplier selection is one of the most important tasks for the manufacturing firm in the apparel supply chain because; it affects the firms' operational performance, market competiveness, and quality of procurement. Moreover, in most of the cases, environmental damage occurs in the upstream side of the supply chain during raw materials extraction. In addition, suppliers are not willing to disclose information about the environmental impact of materials caused by the 
manufacturer because of the high cost related to offering environmental friendly products [29]. For example, Yeh Group (a textile and garment supplier) has spent $\$ 10 \mathrm{~m}$ for equipment and $\$ 3.5 \mathrm{~m}$ for each DyeCoo machines to produce environmentally friendly apparel for Peak Performance, Adidas, Mizuno, and Kjus [30]. In addition, manufacturers want to buy quality products for lower prices which also discourage their suppliers from using environmentally friendly materials and processes. So, it is crucial for the manufacturer to collaborate with their suppliers about environmentally friendly practices to obtain equal benefits from each other.

However, due to increasing environmental awareness, more and more attention has been drawn by apparel manufacturing industries for green supplier evaluation and selection [31] [32]. According to Chen et al., ISO 14000 certificates, green design, green purchasing, research and development ( $\&$ \& ), cleaner production, life cycle assessment, and environmental management systems could be the ideal criteria for green supplier selection [33].

\subsection{Green Branding}

Many companies are focusing on environmental sustainability though green branding initiatives, especially some major apparel and fashion brands such as Patagonia, Stella McCartney, and Loomstate. These brands are incorporating environmental sustainability into their core brand strategy for gaining advantages in the competitive market and maximizing financial benefits [3]. Table 1 represents several fashion brands and their green practices.

Table 1. Green practices taken by the brands [34] [35].

\begin{tabular}{|c|c|}
\hline Apparel brand & Green practices \\
\hline $\mathrm{H} \& \mathrm{M}$ & $\begin{array}{l}\text { Offers products from organic cotton, recycled cotton, } \\
\text { recycled polyester, and vegetable tanned organic leather. } \\
\text { Incentive provided to customer for participation } \\
\text { in collection of used products. }\end{array}$ \\
\hline Levi Strauss & $\begin{array}{l}\text { Less water uses in the production process. } \\
\text { Saving up to } 96 \% \text { of water in the finishing process. }\end{array}$ \\
\hline Patagonia & $\begin{array}{l}\text { Use organic cotton and recycled polyester. } \\
\text { Minimize packaging and transportation waste. } \\
\text { Produce quality products for long term use. }\end{array}$ \\
\hline Eileen Fisher & $\begin{array}{l}\text { Eco-collection line includes classic and well-made garments } \\
\text { that can be worn a long time and seamless knits that } \\
\text { cut down on waste. }\end{array}$ \\
\hline Uniqlo & $\begin{array}{l}\text { Recycle-as fabrics, industrial textiles or fuel. } \\
\text { Reuse-donated to the needy. }\end{array}$ \\
\hline $\begin{array}{l}\text { Bonluxe } \\
\text { (Renowned luxury brand of } \\
\text { intimate apparel, Hong Kong) }\end{array}$ & $\begin{array}{l}\text { Issues a US\$10 (about HK\$80) cash voucher to customers for } \\
\text { returning each used bra as an incentive to recycle. }\end{array}$ \\
\hline $\begin{array}{l}\text { Wacoal } \\
\text { (Intimate apparel brand, } \\
\text { Hong Kong) }\end{array}$ & $\begin{array}{l}\text { Consumers can convert US\$ } 6 \text { cash coupon for new purchase } \\
\text { while returning the old bras of any brand. }\end{array}$ \\
\hline
\end{tabular}




\subsection{Green Marketing}

Recently, green marketing is one of the key aspects for manufacturing companies to trigger sustainable consumer support from the environmental perspective. Green marketing concepts deal with products, production process, the manufacturing industry, and entire supply chain for mass market promotion. However, for green marketing, sustainable product information should be included in the actual product features as a starting point [36]. Eco-design and eco sourcing are very crucial for the overall sustainable development of a company to facilitate green marketing. In the apparel and fashion industries, two features are associated with product: the first is internal (e.g. product style, product design, product color, product care, and product quality) while the second is external (e.g. pricing, packaging, country of origin and product brand) [37]. So, during the marketing of eco-friendly product "ethical consumption attitudes" need to be mentioned clearly through both internal and external features. Launching enormous quantities of green products in the market might be another possible way for green marketing to succeed.

\section{Challenges and Future Research Direction}

- Adoption of green technology increases a company's green image, but is still a burden for the manufacturer who wants technology assistance and financial support from external organizations [17]. T.T. Muthukumarana et al. had researched sustainable energy use from the fabric manufacturing stage to gradual distribution to the end customer and also indicated future research direction to analyze efficient energy use for the whole apparel supply chain [38]. In addition, the literature [14] has presented two case studies on the Chinese apparel and textile industry to discuss energy consumption constraints and also propose an analytical model to determine optimal energy saving strategies in a low carbon supply chain. In the future, this study could be applied to other countries.

- Several challenges exist to incorporate a recycling program in a manufacturing firm such as low demand for recycled product among consumers, lack of technology and equipment, and high costs of production [39]. There are certain scenarios where reuse and recycling are not beneficial for the environment, for example, when replacement rates in the market are low, and recycling processes require harmful chemicals [19]. On the other hand, used textile collection efficiency is very low. One of the procedures to improve collection efficiency is to solve this challenge, is to apply a game-theoretic analytical study has been proposed by TM Choi et al., [36].

- Future research could focus on finding strategies to optimize these barriers. Although, TM Choi et al., have researched how to increase the collection efficiency in "used intimate apparel collection" programs [36], it is also necessary to conduct further research on how to increase collection efficiency and economic benefits of used apparel collections in the apparel supply chain. 
- In most cases, eco-designed garments are considered not trendy or unfashionable, and unattractive to fashion consumers. Designing fashionable trendy and sustainable garments is a big challenge for the sustainable apparel industry. In the future, trendy and fashionable green design should not be totally ignored while designing textile products [17]. Study [40] has proposed "reDesign canvas" which is a design tool to mitigate sustainable fashion design barriers. So, in the green design movement, more attention could be given on the concept of redesign to mitigate eco-design, reuse and recycling barriers.

- Life Cycle Assessment (LCA) is an integral component in determining environmental footprint measurements. Calculating relevant environmental risk and opportunities in the apparel supply chain is still new phenomena incurring major technological as well as financial challenges for GSCM. In addition, most of the time life cycle assessment (LCA) involves life-cycle inventory (LCI) data for environmental footprint calculations. This LCI data is often compiled from inadequate sources and becomes divergent while using it for life-cycle environmental performance evaluations [21]. Honest collaborative information sharing among supply chain partners plays an important role in LCA. In the future, cloud computing, internet of things, and Web 2.0 and their applications in manufacturing and the service industries could bring solutions to these kinds of information collaboration problems in the supply chain.

- Primarily, green apparel product availability and accessibility in the mass market is a challenge compared to fashionable and trendy products. Secondly, most of the time green product information is not clearly mentioned in the product features or not easy understandable by the customer. Thirdly, green marketing strategy flows from a top-down approach where consumer concepts and feedback are hardly considered. It is evident that retailer has the power to influence the manufacturer for launching green products in the market [41]. To solve these problem retailers can play an important role in green marketing because they have close relations with consumers as well as with manufacturing companies in their supply chain. So, in the apparel supply chain, retail-oriented green marketing programs could require further research in the future.

\section{Conflicts of Interest}

The authors declare no conflicts of interest regarding the publication of this paper.

\section{References}

[1] Big Oil.

https://www.ecowatch.com/fast-fashion-is-the-second-dirtiest-industry-in-the-worl d-next-to-big--1882083445.html

[2] Shen, B., Li, Q., Dong, C. and Perry, P. (2017) Sustainability Issues in Textile and 
Apparel Supply Chains. Sustainability, 9, 1592. https://doi.org/10.3390/su9091592

[3] Kim, H.S. and Hall, M.L. (2015) Green Brand Strategies in the Fashion Industry: Leveraging Connections of the Consumer, Brand, and Environmental Sustainability. In: Choi, T.M. and Cheng, T., Eds., Sustainable Fashion Supply Chain Management, Springer, Cham, 31-45. https://doi.org/10.1007/978-3-319-12703-3 2

[4] Nema, N., Soni, S.R., Talankar, A. and Nougriaya, S. (2013) Green Supply Chain Management Practices in Textile and Apparel Industries: Literature Review. International Journal of Engineering Technology \& Management Research, 1, 330-336.

[5] Lo, C.K., Yeung, A.C. and Cheng, T.C.E. (2012) The Impact of Environmental Management Systems on Financial Performance in Fashion and Textiles Industries. International Journal of Production Economics, 135, 561-567. https://doi.org/10.1016/j.ijpe.2011.05.010

[6] Sarkis, J., Zhu, Q. and Lai, K.H. (2011) An Organizational Theoretic Review of Green Supply Chain Management Literature. International Journal of Production Economics, 130, 1-15. https://doi.org/10.1016/j.ijpe.2010.11.010

[7] Lee, S.Y. (2015) The Effects of Green Supply Chain Management on the Supplier's Performance through Social Capital Accumulation. Supply Chain Management: An International Journal, 20, 42-55. https://doi.org/10.1108/SCM-01-2014-0009

[8] Saberi, S., Cruz, J.M., Sarkis, J. and Nagurney, A. (2018) A Competitive Multiperiod Supply Chain Network Model with Freight Carriers and Green Technology Investment Option. European Journal of Operational Research, 266, 934-949. https://doi.org/10.1016/j.ejor.2017.10.043

[9] Diekamp, K. and Koch, W. (2010) Eco Fashion: Top-Labels entdecken die Grüne Mode. Stiebner Verlag GmbH, Grünwald, Germany.

[10] Strähle, J. and Müller, V. (2017) Key Aspects of Sustainability in Fashion Retail. In: Strähle, J., Ed., Green Fashion Retail, Springer, Singapore, 7-26. https://doi.org/10.1007/978-981-10-2440-5 2

[11] Agi, M.A. and Nishant, R. (2017) Understanding Influential Factors on Implementing Green Supply Chain Management Practices: An Interpretive Structural Modelling Analysis. Journal of Environmental Management, 188, 351-363. https://doi.org/10.1016/j.jenvman.2016.11.081

[12] Eryuruk, S.H. (2012) Greening of the Textile and Clothing Industry. Fibres \& Textiles in Eastern Europe, 95, 22-27.

[13] Pathirana, S. and Yarime, M. (2018) Introducing Energy Efficient Technologies in Small- and Medium-Sized Enterprises in the Apparel Industry: A Case Study of Sri Lanka. Journal of Cleaner Production, 178, 247-257. https://doi.org/10.1016/j.jclepro.2017.12.274

[14] Shen, B., Ding, X., Chen, L. and Chan, H.L. (2017) Low Carbon Supply Chain with Energy Consumption Constraints: Case Studies from China's Textile Industry and Simple Analytical Model. Supply Chain Management: An International Journal, 22, 258-269. https://doi.org/10.1108/SCM-05-2015-0197

[15] Hasan, A.K., Bhuiyan, A.M.W. and Mojumdar, M.R.R. (2011) An Endeavour to Improve Lighting Efficiency in RMG (Ready-Made Garments) Industry: Perspective Bangladesh. International Journal of Emerging Science and Engineering, 5, 28-35.

[16] Jananthan, R., Ameer, S. and Shiyamini, R. (2006) Comparative Study of Energy Assessment from Apparel Industries: The Context of Sri Lanka. First International Conference on Industrial and Information Systems, Peradeniya, Sri Lanka, 8-11 August 2006, 217-220. https://doi.org/10.1109/ICIIS.2006.365726

[17] Moon, K.K.L., Youn, C., Chang, J.M. and Yeung, A.W.H. (2013) Product Design 
Scenarios for Energy Saving: A Case Study of Fashion Apparel. International Journal of Production Economics, 146, 392-401. https://doi.org/10.1016/j.jclepro.2017.12.274

[18] Fortuna, L.M. and Diyamandoglu, V. (2017) Optimization of Greenhouse Gas Emissions in Second-Hand Consumer Product Recovery through Reuse Platforms. Waste Management, 66, 178-189. https://doi.org/10.1016/j.wasman.2017.04.032

[19] Sandin, G. and Peters, G.M. (2018) Environmental Impact of Textile Reuse and Recycling-A Review. Journal of Cleaner Production, 184, 353-365. https://doi.org/10.1016/j.jclepro.2018.02.266

[20] Scur, G. and Barbosa, M.E. (2017) Green Supply Chain Management Practices: Multiple Case Studies in the Brazilian Home Appliance Industry. Journal of Cleaner Production, 141, 1293-1302. https://doi.org/10.1016/j.jclepro.2016.09.158

[21] Xing, K., Qian, W. and Zaman, A.U. (2016) Development of a Cloud-Based Platform for Footprint Assessment in Green Supply Chain Management. Journal of Cleaner Production, 139, 191-203. https://doi.org/10.1016/j.jclepro.2016.08.042

[22] Yasin, S., Behary, N., Perwuelz, A. and Guan, J. (2018) Life Cycle Assessment of Flame Retardant Cotton Textiles with Optimized End-of-Life Phase. Journal of Cleaner Production, 172, 1080-1088. https://doi.org/10.1016/j.jclepro.2017.10.198

[23] Hu, Z.H. (2016) Distribution, Transshipment, and Sustainable Logistics for Fashion Products. In: Choi, T.M., Ed., Analytical Modelling Research in Fashion Business, Springer, Singapore, 155-196. https://doi.org/10.1007/978-981-10-1014-9 9

[24] Ramos, T.R.P., Gomes, M.I. and Barbosa-Póvoa, A.P. (2014) Planning a Sustainable Reverse Logistics System: Balancing Costs with Environmental and Social Concerns. Omega, 48, 60-74. https://doi.org/10.1016/j.omega.2013.11.006

[25] Abdullah, N.A.H.N. and Yaakub, S. (2014) Reverse Logistics: Pressure for Adoption and the Impact on Firm's Performance. International Journal of Business and Society, 15, 151.

[26] Geng, R., Mansouri, S.A. and Aktas, E. (2017) The Relationship between Green Supply Chain Management and Performance: A Meta-Analysis of Empirical Evidences in Asian Emerging Economies. International Journal of Production Economics, 183, 245-258. https://doi.org/10.1016/j.ijpe.2016.10.008

[27] Stål, H.I. and Corvellec, H. (2018) A Decoupling Perspective on Circular Business Model Implementation: Illustrations from Swedish Apparel. Journal of Cleaner Production, 171, 630-643. https://doi.org/10.1016/j.jclepro.2017.09.249

[28] Agrawal, S., Singh, R.K. and Murtaza, Q. (2015) A Literature Review and Perspectives in Reverse Logistics. Resources, Conservation and Recycling, 97, 76-92. https://doi.org/10.1016/j.resconrec.2015.02.009

[29] Ma, X., Ho, W., Ji, P. and Talluri, S. (2018) Contract Design with Information Asymmetry in a Supply Chain under an Emissions Trading Mechanism. Decision Sciences, 49, 121-153. https://doi.org/10.1111/deci.12265

[30] Hepburn, S. (2015) Nike and Adidas Show Cautious Support for Eco-Friendly Dye Technology. The Guardian, 24.

[31] Geng, R., Mansouri, S.A. and Aktas, E. (2017) The Relationship between Green Supply Chain Management and Performance: A Meta-Analysis of Empirical Evidences in Asian Emerging Economies. International Journal of Production Economics, 183, 245-258. https://doi.org/10.1016/j.ijpe.2016.10.008

[32] Guo, Z., Liu, H., Zhang, D. and Yang, J. (2017) Green Supplier Evaluation and Selection in Apparel Manufacturing Using a Fuzzy Multi-Criteria Decision-Making 
Approach. Sustainability, 9, 650. https://doi.org/10.3390/su9040650

[33] Chen, C.C., Tseng, M.L., Lin, Y.H. and Lin, Z.S. (2010, December) Implementation of Green Supply Chain Management in Uncertainty. 2010 IEEE International Conference on Industrial Engineering and Engineering Management, Macao, 7-10 December 2010, 260-264. https://doi.org/10.1109/IEEM.2010.5674461

[34] Chow, P.S. and Li, C.K. (2018) Towards Closed-Loop Fashion Supply Chains-Reflections from Retailer-Facilitated Used Apparel Collection Programs. In: Chow, P.S., Chiu, C.H., Yip, A., Tang, A., Eds., Contemporary Case Studies on Fashion Production, Marketing and Operations, Springer, Singapore, 219-239. https://doi.org/10.1007/978-981-10-7007-5 13

[35] Choi, T.M., Chow, P.S., Lee, C.H. and Shen, B. (2018) Used Intimate Apparel Collection Programs: A Game-Theoretic Analytical Study. Transportation Research Part E: Logistics and Transportation Review, 109, 44-62.

https://doi.org/10.1016/j.tre.2017.10.017

[36] Saari, U.A., Fritz, M.M., Mäkinen, S.J. and Baumgartner, R.J. (2018) Designing Green Marketing across Industries: A Conceptual Framework and Implications for Consumers and Transdisciplinary Research. In: Leal Filho, W., Ed., Handbook of Sustainability Science and Research, Springer, Cham, 581-596.

https://doi.org/10.1007/978-3-319-63007-6 36

[37] Jung, H.J., Kim, H. and Oh, K.W. (2016) Green Leather for Ethical Consumers in China and Korea: Facilitating Ethical Consumption with Value-Belief-Attitude Logic. Journal of Business Ethics, 135, 483-502. https://doi.org/10.1007/s10551-014-2475-2

[38] Muthukumarana, T.T., Karunathilake, H.P., Punchihewa, H.K.G., Manthilake, M.M.I.D. and Hewage, K.N. (2018) Life Cycle Environmental Impacts of the Apparel Industry in Sri Lanka: Analysis of the Energy Sources. Journal of Cleaner Production, 172, 1346-1357. https://doi.org/10.1016/j.jclepro.2017.10.261

[39] Larney, M. and Van Aardt, A.M. (2010) Case Study: Apparel Industry Waste Management: A Focus on Recycling in South Africa. Waste Management \& Research, 28, 36-43. https://doi.org/10.1177/0734242X09338729

[40] Kozlowski, A., Searcy, C. and Bardecki, M. (2018) The Redesign Canvas: Fashion Design as a Tool for Sustainability. Journal of Cleaner Production, 183, 194-207. https://doi.org/10.1016/j.jclepro.2018.02.014

[41] Delai, I. and Takahashi, S. (2013) Corporate Sustainability in Emerging Markets: Insights from the Practices Reported by the Brazilian Retailers. Journal of Cleaner Production, 47, 211-221. https://doi.org/10.1016/j.jclepro.2012.12.029 